\title{
Profitabilitas, Likuiditas, Ukuran Perusahaan dan Nilai Perusahaan
}

\author{
Kadek Asri Damayani ${ }^{1}$ \\ Ni Gusti Putu Wirawati ${ }^{2}$ \\ 1,2Fakultas Ekonomi dan Bisnis Universitas Udayana, Indonesia \\ ${ }^{*}$ Correspondences : damayaniasri19@gmail.com
}

\begin{abstract}
ABSTRAK
Tujuan penelitian ini adalah dengan mengetahui pengaruh likuidias, profitabilitas, dan ukuran perusahaan terhadap nilai perusahaan. Penelitian menggunakan perusahaan real estate dan properti dari tahun 2017-2019 yang terdaftar di Bursa Efek Indonesia sebagai populasi dalam penelitian ini. Metode penentuan sampel menggunakan teknik purposive sampling. Jumlah sampel penelitian sebanyak 28 perusahaan dengan periode amatan 3 tahun maka menghasilkan 84 sampel amatan. Hipotesis dalam penelitian ini diuji dengan menggunakan teknik analisis regresi linier berganda. Hasil analisis menunjukan bahwa profitabilitas, likuiditas dan ukuran perusahaan berpengaruh positif pada nilai perusahan sektor properti dan real estate. Jadi dapat disimpulkan bahwa profitabilitas, likuiditas dan ukuran perusahaan memegang peran penting untuk mennetukan nilai peusahaan sektor properti dan real estate.
\end{abstract}

Kata Kunci: Profitabilitas; Likuiditas; Ukuran Perusahaan; Nilai Perusahaan.

\section{Profitability, Liquidity, Firm Size and Firm Value}

\section{ABSTRACT}

The purpose of this study was to determine the effect of liquidity, profitability, and firm size on firm value. This study uses real estate and property companies from 2017-2019 listed on the Indonesia Stock Exchange as the population in this study. The method of determining the sample using purposive sampling technique. The number of research samples was 28 companies with an observation period of 3 years, resulting in 84 samples of observations. The hypothesis in this study was tested using multiple linear regression analysis techniques. The results of the analysis show that profitability, liquidity and firm size have a positive effect on the value of the property and real estate sector companies. So it can be concluded that profitability, liquidity and company size play an important role in determining the value of companies in the property and real estate sectors.

Keywords: $\quad$ Profitability; Liquidity; Firm Size; Firm Value.

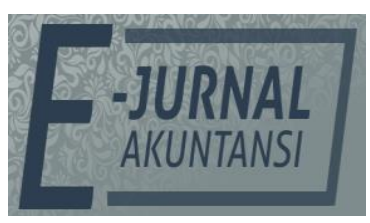

e-ISSN 2302-8556

Vol. 32 No. 1

Denpasar, Januari 2022

Hal. 17-29

DOI:

10.24843/EJA.2022.v32.i01.p02

PENGUTIPAN:

Damayani, K. A. \& Wirawati, N. G. P. (2022). Profitabilitas,

Likuiditas, Ukuran Perusahaan dan Nilai Perusahaan. E-Jurnal Akuntansi, 32(1), 17-29

RIWAYAT ARTIKEL:

Artikel Masuk: 20 Agustus 2021 Artikel Diterima: 12 Januari 2022

Artikel dapat diakses : https://ojs.unud.ac.id/index.php/Akuntansi/index 


\section{PENDAHULUAN}

Persaingan perusahaan di era globalisasi tentunya akan semakin ketat, hal ini terlihat dari beberapa perusahaan besar seperti Google, Microsoft, Apple, dan Toyota saat ini sedang berlomba-lomba untuk memenangkan persaingan tersebut. Menghadapi persaingan ini, setiap perusahaan tentunya harus beradaptasi dan terus berinovasi untuk menjadi yang terbaik serta bertahan di tengah persaingan. Perusahaan yang tetap dapat bertahan di tengah persaingan akan meningkatkan nilai dari perusahaan tersebut. Nilai perusahaan yang meningkat seringkali menjadi daya tarik para investor (Kristina \& Wiratmaja, 2018). Menurut Brigham (2007:11) nilai tetap adalah persepsi investor tentang tingkat keberhasilan perusahaan dan harga yang ingin mereka tawarkan saat perusahaan tersebut dijual. Biaya bisnis sering kali dikaitkan dengan harga.

Harga pokok suatu perusahaan berbeda dengan harga saham suatu perusahaan. Harga pokok digunakan sebagai alat ukur untuk menentukan price to book value (PBV). Menurut Brigham \& Houston (2011:152) nilai PBV merupakan tujuan utama dari perusahaan, hal ini disebabkan karena semakin meningkatnya nilai PBV maka kemakmuran para investor juga akan meningkat. Nilai PBV dapat dihitung dengan membandingkan harga saham dengan nilai per lembar saham berdasarkan nilai bukunya.

Tercermin dari harga saham perusahaan, dan fluktuasi harga saham sering dipengaruhi oleh banyak faktor seperti keadaan yang mendasari penerbit, suku bunga dan indeks saham. Keadaan yang mendasari perusahaan dapat dilihat pada keadaan perusahaan tersebut. Unsur kunci untuk melihat suatu perusahaan melalui laporan keuangan dari perusahaan tersebut, melalui laporan keuangan perusahaan juga dapat menunjukkan keberhasilan yang diraih suatu perusahaan. Data laporan keuangan yang dijadikan dasar analisis berupa jumlah laba atau penjualan (Jogiyanto, 2016:188). Dengan melakukan beberapa tindakan anilisis seperti profitabilitas, solvabilitas, rasio likuiditas, serta aktivitas aktivitas usaha, menurut Wiagustini (2014:75).

Profitabilitas merupakan aspek penting yang dijadikan acuan dalam mengukur kemampuan perusahaan dalam menghasilkan keuntungan atau laba sebagai upaya perusahaan tersebut dalam meningkatkan nilai perusahaan (Gryglewicz, 2011). Profitabilas berhubungan dengan pembagian keuntungan kepada pemegang saham, hal ini disebabkan karena profitabilitas diperoleh melalui keuntungan perusahaan setelah bunga dan pajak (Octaviani \& Astika, 2016). Hasil penelitian yang tidak konsisten menggenai profitabilitas bisa dilihat dari hasil penelitian yang dilakukan oleh Mahdaleta et al (2016), Cahyani \& Wirawati (2019), Widayanti \& Yadnya (2020), Pratama \& Wiksuana (2019), Lumoly et al (2018), Indasari \& Yadnyana (2018), Atmaja \& Astika (2018), Novari \& Lestari (2016), Lubis et al (2017), Pratama \& Wiksuana (2019), Mandey et al (2017) menemukan kalau nilai suatu perusahaan secara positif dan signifikan dipengaruhi oleh profitabilitas, selanjutnya hasil ini diperkuat dengan penelitian yang dilakukan oleh (Sugiyanto \& Setiawan, 2019). Hal tersebut berbanding terbalik terhadap riset yang dilakukan oleh Repi et al (2016) yang mengemukakan bahwa berdampaknya negatif serta signifikan terhadap nilai suatu perusahaan adalah disebabkan oleh profitabilias. 
Rasio lainnya yang juga sering digunakan untuk mengukur kinerja dari suatu perusahaan adalah rasio likuiditas. Melalui rasio likuiditas, maka suatu perusahaan dapat diketahui kemampuannya dalam memenuhi kewajiban jangka pendek. Perusahaan dapat terlihat kemampuannya untuk memenuhi kewajiban jangka pendek, dinilai melalui perbandingan dari jumlah hasil kewajiban lancar dan aset lancar. Sebuah perusahaan dikatakan dapat memenuhi segala bentuk kewajiban lancarnya apabila perusahaan memiliki rasio likuiditas yang tinggi, begitupun sebaliknya jika tingkat rasio likuiditas rendah maka perusahaan tersebut dapat dikatakan memiliki kemampuan dalam memenhuhi kewajiban lancarnya yang rendah.

PBV yang dimaksud dalam penelitian ini adalah hubungan antar nilai buku per saham suatu perusahaan dengan harga pasar. Kemampuan perusahaan untuk meningkatkan nilai perusahaannya sangat bergantung pada modal yang diinvestasikan, hal ini dapat ditunjukkan dengan meninjau dan menganalisis rasio PBV. Tingginya rasio PBV yang dimiliki akan mempengaruhi kepercayaan pasar sehingga terwujudlah prospek masa depan bagi para pemegang saham (Nathaniel, 2008). Rasio PBV sama dengan satu menunjukkan bahwa perusahaan berjalan baik karena nilai bukunya yang lebih kecil dibandingkan nilai pasar. Fungsi PVB yang dimana sebagai indicator dalam menilai harga suatu saham, selain fungsi ersebut PVB juga dapat dijadikan sebagai jalannya pertimbangan bagi para investor yang ingin memilih suatu perusahaan yang akan ditanamkan modalnya.

Penelitian sebelumnya yang pernah dilakukan, menunjukkan hasil yang tidak konsisten antar peneliti satu dengan peneliti lainnya. Ketidakonsistenan ini menyebabkan timbulnya persepsi bahwa adanya penyebab atau fator faktor lain yang bisa mempengaruhi likuiditas, profitabilitas, serta ukuran perusahaan terhdap nilai perusahaan. Oleh karena itu peneliti tertarik untuk meneliti mengenai topik ini. Penelitian ini dilakukan pada perusahaan dengan sektor properti dan real estate yang terdaftar pada Bursa Efek Indonesia (BEI).

Kebijakan manajemen yang sering dilakukan untuk membantu meningkatkan nilai perusahaan adalah dengan meningkatkan kemampuan dan keuntungan dari para pemegang saham. Demi mendapatkan respon yang positif dari investor, perushaan harus meningkatkan keuntungan kepada pemegang saham, maka dari itu harga saham sudah pasti akan meningkat. Respon terhdap perusahaan akan memberikan keuntungan bagi para investor hanya dengan dlakukan analisis untuk melihat prospek perusahaan di masa mendatang. Analisis yang sering dilakukan adalah menghitung ROE. Perhitungan ROE akan memberi informasi kepada para investor terkait persentase pengembalian atas modal dalam perusahaan tersebut. Pada umumnya, tingginya nilai ROE yang dimiliki maka kemampuan pemilik perusahaan akan meningkatkan harga saham maupun nilai perusahaan juga akan semakin baik. Hal ini sejalan dengan penelitian Widayanti \& Yadnya (2020), Dewi \& Abundanti (2019), Pratama \& Wiksuana (2019), penelitian-penelitian tersebut menunjukkan bagaimana pentingnya profitabilitas yang berdampak positif serta signifikan terhadap nilai suatu perusahaan, hasil ini diperkuat dengan adanya penelitian ang dilakukan oleh Sugiyanto \& Setiawan (2019).

$\mathrm{H}_{1}$ : Profitabilitas berpengaruh positif pada nilai perusahaan. 
Rasio likuiditas yang tinggi maka akan berbanding lurus dengan kemampuan perusahaan dalam menangani kewajiban jangka pendek. Kemampuan ini tentunya memberikan angina segar bagi para investor. Rasio likuiditas juga tentunya akan mempengaruhii nilai perusahaan, hal ini karena rasio likuiditas yang baik akan menyebabkan para investor berbondong untuk melakukan investasi, apabila permintaan saham yang tinggi maka harga saham perusahaan tersebut akan meningkat. Penelitian yang dilakukan oleh Cahyani \& Wirawati (2019), Putra \& Lestari (2019) menghasilkan bahwa rasio likuiditas memiliki pengaruh positif pada nilai suatu perusahaan.

$\mathrm{H}_{2}$ : Likuiditas berpengaruh positif pada nilai perusahaan.

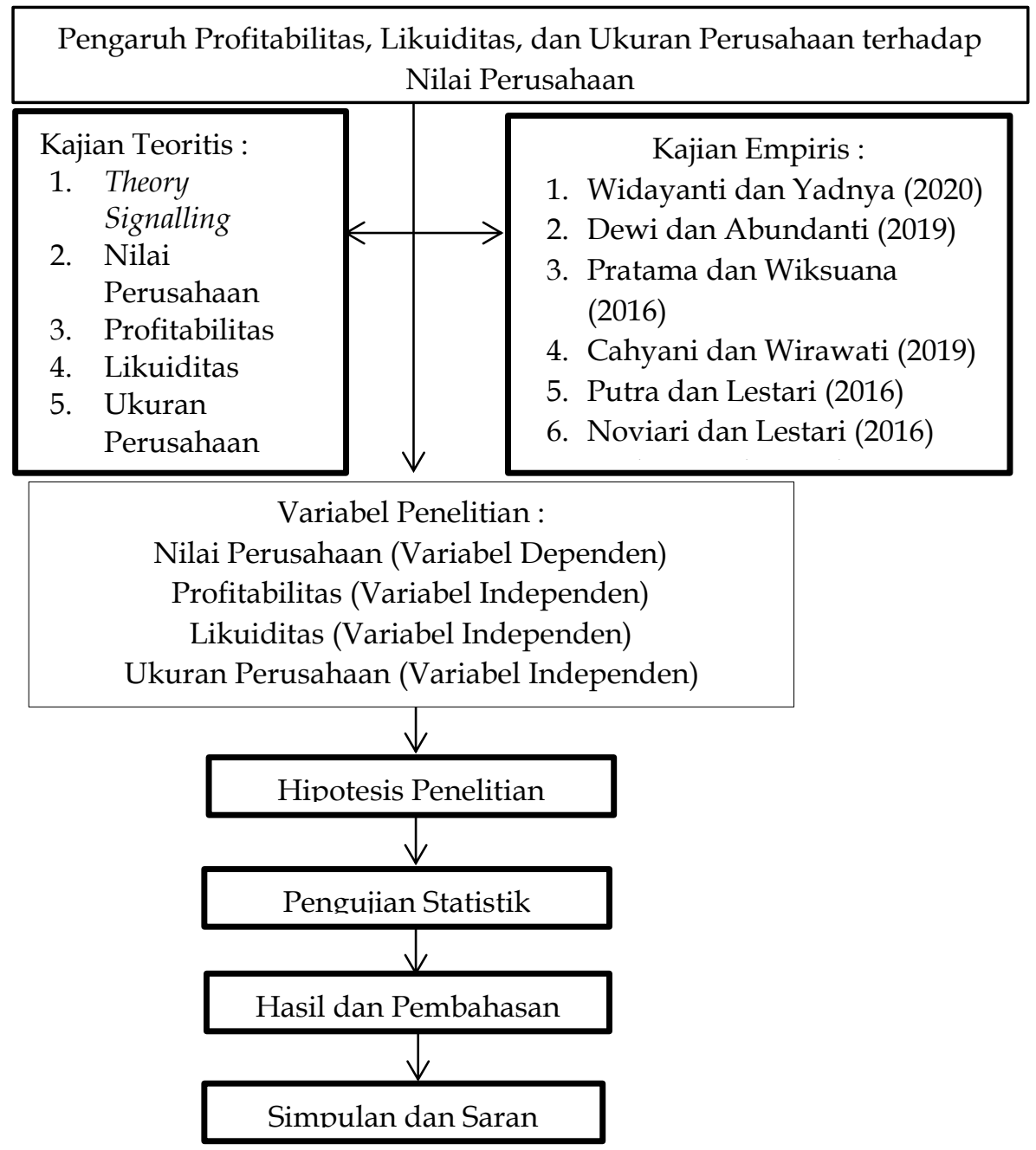

Sumber : Data Penelitian, 2021

Gambar 1. Model Penelitian

Investor akan merespon dan menginvestasikan uangnya pada suatu perusahaan sangat mempengaruhi terhadap ukuran niai perusahaan, ukuran perusahaan yang tinggi dapat mempngaruhi peningkatkan respon positif dari investor (Suniari \& Suaryana, 2017). Ukuran perusahaan sangat mempengaruhi keputusan para investor disebabkan karena perusahaan yang besar akan memiliki kondisi yang lebih stabil dan terjamin. Meningkatnya minat dan permintaan 
investor pada suatu saham perusahaan akan meningkatkan harga saham di pasar modal akan meningkat. Penelitian yang bertemakaan masalah ukuran perusahaan yang dilakukan oleh Novari \& Lestari (2016), Rudangga \& Sudiata (2016) hal yang dapat mempengaruhi nilai positif suatu perusahaan adalah melakukan ukuran perusahaan.

$\mathrm{H}_{3}$ : Kegiatan ukuran perusahaan berpengaruh positif terhadap perusahaan.

\section{METODE PENELITIAN}

Penelitian ini menggunakan pendekatan kuantitatif dengan desain penelitian asosiatif dengan tujuan penelitian yaitu untuk mengetahui pengaruh profitabilitas, likuiditas, dan ukuran suatu perusahaan pada nilai perusahaan. Penelitian ini dilakukan pada perusahaan yang bergerak pada sektor property dan real estate yang terdaftar di Bursa Efek Indonesia (BEI), dengan mengakses melalui situs resmi Bursa Efek Indonesia (BEI) yaitu www.idx.co.id, serta data dalam Indonesian Capital Market Directory (ICMD). Periode penelitian ini sebanyak 3 tahun mulai dari tahun 2017 hingga tahun 2019. Obyek penelitian ini adalah profitabilitas, likuiditas, ukuran perusahaan dan nilai perusahaan pada perusahaan Property dan Real Estate yang tercatat di Bursa Efek Indonesia dari tahun 2017-2019.

Jenis data yang digunakan dalam penelitian ini adalah data kuantitatif yakni data-data keuangan yang mencakup data ukuran perusahaan, profitablitas, dan likuiditas serta nilai suau perusahan terhadap perusahaan property dan real estate yang ada pada daftar BEI tahun 2017-2019. Penelitian ini menggunakan data sekunder. Data sekunder ini dapat diperoleh melalui media perantara, seperti orang lain atau lewat dokumen, data dari biro statistik, majalah maupun keterangan dan publikasi lainnya (Rahyuda, 2004:76). Data sekunder dalam penelitian ini diperoleh dari annual report perusahaan sektor Property dan Real Estate yang tercatat di BEI tahun 2017- 2019 melalui website www.idx.co.id serta data-data dalam Indonesian Capital Market Directory (ICMD).

Populasi pada penelitian ini menggunakan seluruh perusahaan pada sektor property dan real estate yang ada pada Bursa Efek Indonesia dari tahun 2017-2019. Jumlah populasi penelitian ini adalah 61 perusahaan. Jumlah perusahaan yang menjadi sampel dalam penelitian ini berjumlah 28 perusahaan Property dan Real Estate yang terdaftar di Bursa Efek Indonesia. Jumlah tersebut telah diseleksi sesuai dengan model penentuan sampel yang dipakai. Pada sampel penelitian ini menggunakan teknik purposive sampling.

Metode pengumpulan yang dipakai adalah metode dokumentasi, metode dokumentasi yang dimaksud adalah teknik pengumpulan data dengan cara mencari data laporan tahunan yang dipublikasikan dari setiap perusahaan yang menjadi sampel penelitian. Laporan tahunan yang dikumpulkan merupakan laporan tahunan perusahaan tahun 2017 - 2019 melalui website www.idx.co.id serta informasi terhadap kondisi keuangan perusahaan dari Indonesian Capital Market Directory (ICMD). 
Analisis data yang dilakukan dalam penelitian ini menggunakan analisis yang meliputi Analisis Statistik Deskriptif dan Uji Asumsi Klasik (Uji Normalitas, Uji Multikolonearitas, Uji Autokorelasi, Uji Heterokedastisitas, Analisis Linier Berganda, Uji Koefisien Determinasi, Uji Kelayakan Model dan Uji Hipotesis). Dengan variabel yang diteliti adalah nilai suatu perusahaan sebagai variabel bebas $(\mathrm{X})$ meliputi profitabilitas $\left(\mathrm{X}_{1}\right)$ dan variabel dependen $(\mathrm{Y})$, likuiditas $\left(\mathrm{X}_{2}\right)$, serta ukuran perusahaan $\left(X_{3}\right)$.

\section{HASIL DAN PEMBAHASAN}

\section{Tabel 1. Tahap Pemilihan Sampel}

\begin{tabular}{clc}
\hline No & \multicolumn{1}{c}{ Kriteria } & Jumlah \\
\hline 1 & $\begin{array}{l}\text { Perusahaan property dan real estate yang tercatat di BEI selama } \\
\text { periode 2017-2019 }\end{array}$ & 61 \\
2 & Perusahaan yang tidak menampilkan annual report, tidak memiliki & \\
2 & profitabilitas dan likuiditas positif pada tahun 2017-2019 \\
3 & Data Outlier & $(4)$ \\
Jumlah Sampel Akhir & 28 \\
Tahun Pengamatan & 3 \\
Jumlah Pengamatan & 84 \\
\hline
\end{tabular}

Sumber: Data Penelitian, 2021

Berdasarkan Tabel 1, dapat diketahui bahwa jumlah perusahaan yang dijadikan sampel pada penelitian ini yaitu pada perusahaan Property dan Real Estate periode 2017 hingga 2019 yang telah sesuai terhadap kriteria yang telah disepakati sebanyak 28 perusahaan. Rentang periode pengamatan 3 tahun, sampai memperoleh jumlah pengamatan penelitian ini sebanyak 84 pengamatan.

Tabel 2. Analisis Deskripif

\begin{tabular}{lccccc}
\hline Variabel & $\mathrm{N}$ & Minimum & Maximum & Mean & Std. Deviation \\
\hline PBV (Y) & 84 & 14,437 & 2601,369 & 211,015 & 363,842 \\
ROE (X1) & 84 & 0,039 & 32,869 & 7,449 & 7,233 \\
CAR (X2) & 84 & 0,001 & 24,882 & 3,472 & 3,578 \\
Size (X3) & 84 & 16,037 & 32,713 & 27,189 & 3,895 \\
Valid N (listwise) & 84 & & & & \\
\hline
\end{tabular}

Sumber: Data Penelitian, 2021

Tabel 2 menunjukkan dari 84 perusahaan yang diamati memiliki hasil uji analisis statistik deskriptif, hasil pengujian tersebut mendapatkan nilai maximum, standar deviasi, mean dan nilai minimum terhadap setiap variabel dalam penelitian.

Menurut data dari tabel 3 dapat diketahui kalau nilai signifikansi lebih besar dari $0,163(0,05<0,163)$. Hal tersebut menunjukan bahwa residual data dari kegiatan penelitian ini berotasi secara normal. 
Tabel 3. Hasil Uji Normalitas

\begin{tabular}{llc}
\hline & & Unstandardzed Residual \\
\hline $\mathrm{N}$ & & 84 \\
Normal Parametersa,b & Mean & 0,00 \\
& Std. Deviation & 0,263 \\
Most Ekstreme Differences & Absolute & 0,088 \\
& Positive & 0,055 \\
Test Statistic & Negative & 0,088 \\
Asymp. Sig. (2-talend) & & 0,088 \\
\hline
\end{tabular}

Sumber : Data Penelitian, 2021

Tabel 4. Hasil Uji Multikolinearitas

\begin{tabular}{lll}
\hline Model & \multicolumn{2}{l}{ Collinerity statistic } \\
\cline { 2 - 3 } & Tolerance & VIF \\
\hline ROE (X1) & 0,962 & 1,040 \\
CAR (X2) & 0,779 & 1,284 \\
SIZE (X3) & 0,473 & 2,114 \\
\hline
\end{tabular}

Sumber: Data Penelitian, 2021

Tabel 4, menunjukkan hasil dari uji multikolonearitas. Uji ini menghasilkan bahwa nilai tolerance dari profitabilitas (ROE) menunjukkan nilai 0,962, lalu variabel likuiditas (CAR) menunjukkan nilai tolerance 0,779, dan variabel ukuran perusahaan (SIZE) menghasilkan nilai tolerance sebesar 0,473 . Hal ini menunjukkan, nilai tolerance dari masing-masing variabel independen telah memenuhi syarat $(>0,10)$ dan nilai VIF dari masing-masing variabel telah menenuhi syarat $(<10)$. Oleh karena itu, tidak adanya gejala multikoleniaritas pada variabel bebas penelitian ini.

Tabel 5. Hasil Uji Auokorelasi

\begin{tabular}{ccccc}
\hline $\mathrm{D} 1$ & $\mathrm{du}$ & $4-\mathrm{du}$ & $\mathrm{Dw}$ & Keputusan \\
\hline 1,572 & 1,719 & 2,280 & 1,954 & Tidak Ditolak \\
\hline
\end{tabular}

Sumber: Data Penelitian, 2021

Berdasarkan hasil uji autokorelasi pada Tabel 5, menunjukan nilai Dw berada pada posisi tidak ditolak karena du $<$ d $<4$-du $(1,719<1,954<4$-1,179) yang artinya diantara kesalahan pengganggu pada periode $t$ dengan kesalahan pengganggu pada periode $\mathrm{t}-1$ (sebelumnya) bebas masalah autokorelasi.

\section{Tabel 6. Hasil Uji Heteroskedastistas}

\begin{tabular}{lccccc}
\hline \multirow{2}{*}{ Model } & \multicolumn{2}{c}{$\begin{array}{c}\text { Unstandardized } \\
\text { Coefficients }\end{array}$} & $\begin{array}{c}\text { Standardized } \\
\text { Coefficients }\end{array}$ & \multirow{2}{*}{$\mathrm{t}$} & \multirow{2}{*}{ Sig } \\
\cline { 2 - 4 } & $\mathrm{B}$ & Std. Error & Beta & & \\
\hline (Constan) & 0,110 & 0,076 & & 1,449 & 0,151 \\
ROE (X1) & $-0,016$ & 0,045 & $-0,059$ & $-0,347$ & 0,729 \\
CAR (X2) & 0,116 & 0,072 & 0,538 & 1,619 & 0,109 \\
SIZE (X3) & 0,151 & 0,185 & 0,229 & $-0,820$ & 0,415 \\
\hline
\end{tabular}

Sumber: Data Penelitian, 2021

Berdasarkan data dari Tabel 6 dapat diketahui nilai signifikasi variabel profitabilitas (ROE) 0,729, nilai signifikansi variabel likuiditas (CAR) sebesar 0,109 dan nilai signifikansi variabel ukuran perusahaan (SIZE) sebesar 0,415, (Sig.). Hal 
DAMAYANI, K. A. \& WIRAWATI, N. G. P. PROFITABILITAS, LIKUIDITAS, UKURAN...

tersebut menunjukan nilai signifikansi dari ketiga variabel bebas lebih dari 0,05 $(>0,05)$. Maka dapat disimpulkan bahwa tidak terdapat gejala heteroskedastisitas pada model regresi yang digunakan dalam penelitian ini.

Tabel 7. Hasil Analisis Regresi Linier Berganda

\begin{tabular}{lccccc}
\hline \multicolumn{5}{c}{$\begin{array}{c}\text { Unstandardizet } \\
\text { Coefficients }\end{array}$} & \multicolumn{5}{c}{$\begin{array}{c}\text { Unstandardizet } \\
\text { Coefficients }\end{array}$} \\
\hline Model & $\mathrm{B}$ & Std. Error & Beta & $\mathrm{t}$ & Sig. \\
\hline (Constan) & 0,771 & 0,097 & & 7,926 & 0,000 \\
$\operatorname{ROE}\left(\mathrm{X}_{1}\right)$ & 0,017 & 0,007 & 0,254 & 2,312 & 0,023 \\
$\mathrm{CAR}\left(\mathrm{X}_{2}\right)$ & 0,561 & 0,043 & 0,900 & 13,031 & 0,000 \\
SIZE $\left(\mathrm{X}_{3}\right)$ & 0,274 & 0,024 & 1,010 & 11,612 & 0,000 \\
$\mathrm{~F}$ hitung & $: 66,482$ & & & & \\
Signifikansi F & $: 0,000$ & & & & \\
$R$ Square & $: 0,845$ & & & & \\
Adjusted & $R: 0,703$ & & & & \\
Square & & & & & \\
Sumber: Data Penelitian, 2021 &
\end{tabular}

Berdasarkan Tabel 7 dapat dibentuk persamaan regresi dalam penelitian ini sebagai berikut.

$$
\mathrm{Y}=0,771+0,017 \mathrm{X}_{1}+0,561 \mathrm{X}_{2}+0,274 \mathrm{X}_{3}
$$

Berdasarkan persamaan regresi yang terbentuk, maka dapat diartikan nilai konstanta sebesar 0,771 menunjukkan apabila semua variabel bebas sama dengan nol, maka nilai suau perusahaan (PBV) akan bertambah sekitar 77,1 persen. Nilai koefisien variabel ROE menunjukkan angka 0,017, hal ini berarti jika variabel ROE satu persen maka nilai perusahaan akan mengamali peningkatan sebesar 1,7 persen dan variabel lainnya konstan. Nilai koefisien regresi likuiditas (CAR) sebesar 0,561, hal ini berarti likuiditas (CAR) naik satu persen, maka nilai perusahaan (PBV) akan mengalami peningkatan sebesar 56,1 persen dengan asumsi variabel lain konstan. Nilai koefisien dari variabel ukuran perusahaan sebesar 0,274 menunjukkan bahwa apabila ukuran perusahaan naik satu persen, hal ini akan menyebabkan nilai perusahaan mengalami peningkatan sejumlah 27,4 persen dan variabel lainnya dianggap konstan.

Koefisien determinasi dalam penelitian ini sama dengan $1\left(R^{2}=1\right)$ hal ini dapat diinterpretasikan bahwa variabel bebas mempengaruhi secara sempurna variabel terikatnya, sedangkan jika $\left(R^{2}=0\right)$ berarti variable independen tidak berpengaruh terhadap variable dependen. Model regresi terhadap riset ini menunjukkan nilai Adjusted $\mathrm{R}^{2}$ sekitar 0,703, maka hal ini dkattakan sebesar 70,3\% variabel independen profitabilitas (ROE), likuiditas (CAR), dan ukuran perusahan (SIZE) dapat menjelaskan variasi dari variabel dependen yaitu nilai perusahaan (PBV) sedangkan sebesar 29,7 persen dijelaskan oleh variabel lain diluar model.

Hasil uji kelayakan model uji $\mathrm{F}$ dilihat melalui nilai signifikansi, nilai signifikansi penelitian ini menunjukkan nilai 0,000 . Hal ini berarti variabel bahwa profitabilitas (ROE), likuiditas (CAR), dan ukuran perusahan (SIZE) berpengaruh secara simultan terhadap nilai perusahaan (PBV).

Berdasarkan Tabel 7, hasil uji t masing-masing variabel dapat dijelaskan hipotesis pertama menyatakan bahwa profitabilitas (ROE) berpengaruh positif 
terhadap nilai perusahaan (PBV). Hasil uji pada Tabel 7 menunjukkan bahwa profitabilitas (ROE) menunjukkan nilai sig. sejumlah 0,023 serta nilai koefisien bernilai positif sejumlah 0,017 . Hal tersebut berarti $\mathrm{H} 1$ diterima. Variabel ROE memiliki pengaruh positif dan signifikan pada nilai perusahaan. Asumsi kedua mengatakan bahwa likuiditas (CAR) berdampak positif kepada nilai suatu perusahaan (PBV). Beradasarkan hasil pengujian, variabel CAR memiliki nilai signifikan 0,000 dengan nilai koefisien bernilai positif sebesar 0,561. Hal ini menunjukkan bahwa $\mathrm{H} 2$ diterima, dan hasil ini berarti bahwa variabel CAR memiliki pengaruh positif dan signifikan pada nilai perusahaan. Asumsi terakhir mengatakan bahwa ukuran perusahaan (SIZE) berdampak postif terhadap nilai suatu perusahaan (PBV). Berdasarkan hasil pengujian menunjukkan bahwa nilai signfikan sebesar 0,000 dengan nilai koefisien bernilai positif sebesar 0,214 . Hasil ini menunjukkan bahwa $\mathrm{H} 3$ diterima, dan hasil ini diinterpretasi bahwa variabel ukuran perusahaan memiliki penagruh positif pada nilai perusahaan.

\section{SIMPULAN}

Kesimpulan yang di dapatkan dari hasil data analisis serta pembahasan yang sudah diurakan bahwa faktor profitabilitas memiiki pengaruh positif bagi nilai perusahaan. Hal ini berarti apabila laba suatu perusahaan meningkat maka semakin tinggi pula kemampuan perusahaan dalam membagikan dividen. Tingginya dividen yang dibagikan dapat menarik perhatian bagi investor sehingga dapat menanamkan modalnya sebanyak-banyak terhadap suatu perusahaan. Maka semakin berminatnya investor yang berminat memiliki saham perusahaan tersebut yang terjadi adalah harga saham akan meningkat, jika harga saham meningkat maka nilai perusahaan juga akan meningkat. Likuiditas memiliki pengaruh positif pada nilai perusahaan. Ukuran perusahaan mempengaruhi nilai perusahaan secara positif, perusahaan yang besar, menandakan perusahaan tersebut memiliki kondisi yang stabil dan berkembang sangat pesat. Hal ini tentunya akan menarik minat para investor, respon positif dari investor akan meningkatkan nilai perusahaan.

Sedikit saran untuk Perusahaan diharapkan lebih sadar pada peningkatan proporsi profitabilitas, lebih hati-hati pada rasio likuiditas, dan fokus juga pada strategi peningkatan ukuran perusahaan. Sehingga peningkatan pada aspek tersebut, dapat menjadi sinyal bagi investor untuk meningkatkan investasinya pada perusahaan, yang nantinya dapat menjadi stimulus bagi peningkatan nilai perusahaan. Selanjutnya untuk Peneliti selanjutnya diharapkan dapat memperluas sampel riset selain menggunakan real estate serta sector properti, dapat juga menggunakan perusahaan sektor lainnya yang terdaftar di BEI. Sehingga dapat menggambarkan variabel terkait secara lebih baik dan kompleks. Peneliti selanjutnya juga dapat menambahkan variabel baru atau model barumoderasi atau mediasi pada variabel terkait, sehingga dapat menjelaskan variabel nilai perusahaan secara lebih baik.

\section{REFERENSI}

Agrawal, S. P., Monem, R. M., \& Ariff, M. (1996). Price to Book Ratio as a Valuaion Model: An Empirical Investigation. Finance India, 10(2), 333-344. http:// citeseerx.ist.psu.edu/viewdoc/download?doi=10.1.1.570.3053\&rep=rep1 
\&type $=$ pdf

Andiani, N. W. S., \& Gayatri, G. (2018). Pengaruh Volume Perdagangan Saham, Volatilitas Laba, Dividend Yield, dan Ukuran Perusahaan Pada Volatilitas Harga Saham. E-Jurnal Akuntansi, 24, 2148. https://doi.org/10.24843/ eja.2018.v24.i03.p19

Anugerah, K.H.G., \& Suryanawa, I.K. (2019). Pengaruh Leverage dan Ukuran Perusahaan Pada Nilai Perusahaan. E-Jurnal Akuntansi, 26, 2324. https://doi.org/10.24843/eja.2019.v26.i03.p24

Arifah, E., \& Wirajaya, I. G. A. (2018). Pengaruh Pengungkapan Enterprise Risk Management Terhadap Nilai Perusahaan Dengan Ukuran Perusahaan, Leverage, dan Profitabilitas Sebagai Variabel Kontrol. E-Jurnal Akuntansi, 25, 1607. https://doi.org/10.24843/eja.2018.v25.i02.p30

Atmaja, I. G. N. Y. D., \& Astika, I. B. P. (2018). Pengaruh Profitabilitas, Leverage, Dan Modal Kerja Pada Nilai Perusahaan Dengan Csr Sebagai Variabel Intervening. E-Jurnal Akuntansi, $\quad 24, \quad 1$. https://doi.org/10.24843/eja.2018.v24.i01.p01

Brigham, E. F., dan Houston, J. F. (2011). Essentials of Financial Management. (A.A. Y, Ed.) (11th ed.). Jakarta: Salemba Empat.

Brigham, Eugene dan Houston Joel. ( 2007). Manajemen Keuangan. Jakarta : Erlangga

Cahyani, G. A. P., \& Wirawati,N. G. P.(2019). Pengaruh Likuiditas, Kebijakan Dividen, Profitabilitas, dan Ukuran Perusahaan pada Nilai Perusahaan. EJurnal Akuntans,27, 1263. https:/ / doi.org/10.2483/ eja. 2019.v27.i02.p16

Chen, Li Yueh. (2004). Examining the Effect of Organization Culture and Leadership Behaviors on Organizational Commitment, Job Satisfaction, Job Performance at Small and Middle-Sized Firma of Taiwan. Journal of American Academy of Business, 1(2): 432-38

Chumaidah. (2018). Sekolah Tinggi Ilmu Ekonomi Indonesia ( Steisia ) Surabaya. Jurnal Ilmu Dan Riset Akuntansi, 7(3).

Dewi, N. P. I. K., \& Abundanti, N. (2019). Pengaruh Leverage Dan Ukuran Perusahaa Sebagai Variabel Mediasi. E-Jurnal Manajemen, 8(5), 3028-3056.

Dwi Astutik. (2017). Pengaruh Aktivitas Rasio Keuangan Terhadap Nilai Perusahaan (Studi Pada Industri Manufaktur). Jurnal STIE Semarang, 9(1), 3249.

Fenandar, Gany Ibrahim dan Raharja Surya. (2012). Pengaruh Keputusan Investasi, Keputusan Pendanaan, dan Kebijakan Deviden Terhadap Nilai Perusahaan. Diponegoro Journal of Accounting, 1 (2)

Jogiyanto, H. (2016). Teori Portofolio dan Analisis Investasi (10th ed.). Yogyakarta: BPFE.

Ghozali, Imam. (2016). Aplikasi analisis Multivariete dengan program IBM SPSS 23. Badan Penerbit Universitas Diponegoro, Semarang

Gill, A., \& Obradovich, J. (2012). The impact of corporate Governance an d financial loverage $\mathrm{n}$ the value of american firms. International Research Jurnal Of Finance and Economics, 91(February), 46-56.

Hardian, A. P., \& Asyik, N. F. (2016). Kinerja Keungan Dan Ukuran Peerusahaan Terhadap Nilai Perusahaan, Csr Sebagai Vriabel Moderasi. Journal Ilmu Dan Riset Akuntnsi, 5(9), 1-16. 
Ju Chen, Li and Yu Chen, Shun. (2011). The Influence of profitability n Firm Vale with Capital Strukture as The Mediator and Firm Size and Industry as Moderator . Investmet Management and Financial Innovatons. Vol. 8, Issue 3

Indasari, A. P., \& Yadnyana, I.k. (2018). Pengaruh Prfitabilitas, Growth Opportunity, Likuiditas, dan Struktur Modal Pada Nilai Perusahaan. E-Jurnal Akuntansi, 2018(1), 714-746. https:// doi.org/10.24843/EJA.2018.v22.i01.p27

Indriyani, E. (2017). Pengaruh Ukuran Perusahaan dan Profitabilitas Terhadap Nilai Perusahaan. Akuntabilitas, 10(2), 4394-4422. https://doi.org/10.15408/akt.v10i2.4649

Kristina, I. G. A. R., \& Wiratmaja, I. D. N. (2018). Pengaruh Board Diversity and Intellectual Capital pada nilai perusahaan. E- Jurnal Akuntansi, 22, 2313. https://doi.org/10.24843/eja.v22.i03.p25

Kurniasih, T., \& Ratna Sari, M. (2013). Pengaruh Return on Assets, Leverage, Corporate Governnce, Ukuran Perusahaan dan Kompensasi Rugi Fiskal pada Tax Avoidance. Buletin Study Ekonomi, 18(1), 58-66

Kusumadilaga, R. (2010). Traffic generated by shopping centres in Adelaide ( Australia). In E-Jurnal Akuntansi Fakultas Ekonomi, Universitas Diponegoro (Vol. 11, Issue 2).

Lischewski, J., \& Voronkova, S. (2012). Size, Value and liquidity. Do They Really Matter onan Emerging Stock Market? Emerging Markets Review, 13(1), 8-25. https://doi.org/10.1016/j.ememar. 2011.09.002

Lubis, I. L., Sinaga, B. M., \& Sasongko, H. (2017). Pengaruh Profitbilitas, Struktur Modal, Dan Liquiditas Terhadap Nilai Perusahaan. Jurnal Aplikasi Bisnis Dan Manajemen, 3(3),485-465. https://doi.org/10.17385 /jabm.3.3.458

Lumoly, S., Murni, S., \& Untu, V. N. (2018). Pengaruh Likuiditas, Ukuran Perusahaan Dan Profiyabilitas Terhadap Nilai Perusahaan (Studi pada Perusahaan Logam dan Sejenisnya yang Terdaftar di Bursa Efek Indonesia). Jurnal EMBA: Jurnal Riset Ekonomi, Manajemen, Bisnis Dan Akuntansi, 6(3), 1108-1117. https://doi.org/10.35794/emba.v6i3.20072

Mahdaleta, E., Muda, I., \& Nasir, G. M. (2016). Effects of Capital Structure and Profitability on Corporate Value with Company Size as the Moderating Variable of Manufacturing Companies Listed on Indonesia Stock Exchange. Academic Journal of Economic Studies, 2(3), 30-43.

Madney, S. R., Pangemanan., S. S.,\& pangerapan, S.(2017). Analisis pengaruh Insider Ownership, Leverage, Dan Profitabilitas Terhadap Nilai Perusahaan Pada Sektor Perusahaan Manufaktur Di Bursa Efek Indonesia Periode Tahun 2013-2015. Jurnal EMBA: Jurnal Riset Ekonomi, Manajemen, Bisnis Dan Akuntansi, 5(2), 1463-1473. https:/ / doi.org/10.35794/emba.v5i2.16213

Menawati, M. N., \& Astika, I. P. (2017). Pengaruh Rentabilitas Dan Likuiditas Pada Jumlah Opsi Saham Dan Dampaknya Pada Nilai Perusahaan. E-Jurnal Akuntansi, 18(3), 1915-1942.

Nathaniel, N. (2008). Analisis faktor-faktor yang mempengaruhi return saham (Studi pada saham-saham real estate and property di Bursa Efek Indonesia periode 2004-2006). Jurnal Bisnis Indonesia, 5(2).

Novari, P., \& Lestari, P. (2016). Pengaruh Ukuran Perusahaan, Leverage, Dan Profitabilitas Terhadap Nilai Perusahaan Pada Sektor Properti Dan Real Estate. E-Jurnal Manajemen Universitas Udayana, 5(9), 252428. 
Nurhayati , M. (2013). Pofitabilitas likuiditas dan ukuran per. Jurnal Keuangan Dan Bisnis, 5(2), 144-153.

Oktaviaani, N., \& Astika, I. (2016). Provitabiitas dan Leverage Sebagai Pemoderasi Pengaruh Kebijakan Dividen Pada Nilai Perusahaan. E-Jurnal Manajemen Universitas Udayana, 5(9), 252428

Pratama, I. A., \& Wiksuana, I. (2019). Pengaruh Leverage Dan Ukuran Perusahaan Terhadap Nilai Perusahaan Dengan Profitabilitas Sebagai Variabel Mediasi. E-Jurnal Manajemen Universitas Udayana, 8(5), 3028. https://doi.org/10.24843/ejmunud.2019.v08.i05.p16

Putra, A. N. D., \& Lestari, P. V. (2019). Pengaruh Profitabilitas, Likuiditas, Dan Ukuran Perusahaan Terhadap Nilai Perusahaan Melalui Kebijakan Dividen. E-Jurnal Manajemen Universitas Udayana, 8(5), 3275. https://doi.org/10.24843/ejmunud.2019.v08.i05.p25

Rahyuda, I Ketut., I Gusti Wayan Murjana Yasa dan Ni Nyoman Yuliarni. (2004). Metodologi Penelitian. Universitas Udayana : Fakultas Ekonomi

Repi, S., Murni, S., Faktor-Faktor, D. A., Repi, S., Murni, S., Adare, D., Ekonomi, F., Bisnis, D., Manajemen, J., Sam, U., \& Manado, R. (2016). Faktor-Faktor Yang Mempengaruhi Nilai Perusahaan Subsektor Perbankan Pada Bei Dalam Menghadapi Mea the Factors That Influenced Company Value in Banking Subsecktor At Idx in the Face of Mea. Jurnal EMBA, 1814(1), 181-191.

Riska, P., Dewi, A., \& Putri, I. G. A. M. D. (2017). Pengaruh Kebijakann Dividen Pada Nilai Perusahaan Dengan Pengungkapan Csr Dan Good Corporate Governance Sebagai Pemoderasi. E-Jurnal Akuntaansi, 2017(1), 173-199.

Ryan, M., Daeng, Y., Gusti, N., \& Wirawati, P. (2017). Pengaruh Profitabilitas Dan Kepemilikan Manajerial Pada Nilai Perusahaan Dengan Pengungkapan CSR Sebagai Variabel Pemoderasi. E-Jurnal Akuntansi, 21(3), 2052-2080. https:// doi.org/10.24843/EJA.2017.v21.i03.p13

Sari, I. K., \& Yasa, G. W. (2016) Pengaruh Penerapan Good Corporate Governance, profitabiltas dan Likuiditas terhadap Peringkat Obligasi. Journal of Chemical Information and Modeling, 53(9), 1689-1699.

Sugiyanto dan Tato Setiawan. (2019). Pengaruh Likuiditas Profitabilitas dan Good Corporate Governance Terhadap Nilai Perusahaan. Prosiding Seminar Nasional HUMANIS 2019 Tanggal 7 Desember 2019

Sugiyono. (2014). Metode Penelitian Bisnis (Cetakan ke 17). Bandung : CV. Alfabeta

Sugiyono. (2016). Metode Penelitian Bisnis. Bandung: AlfaBeta

Suniari, I. A. M., \& Suaryana, I. A. (2017). Determinan Pengungkapan Modal Intelektual Dan Dampaknya Terhadap Nilai Perusahaan. Jurnal Riset Akuntansi Aksioma, 15(2), 53. https:/ / doi.org/10.29303/aksioma.v15i2.7

Tandanu, Andrew dan Lukman Suryadi. (2020). Ppengaruh Profitabilitas, Likuiditas, Ukuran Perusahaan terhadap Nilai Perusahaan. Jurnal Multiparadigma Akuntansi Tarumanagara. Vol.2 , No.1, Januari 2020 : 108 - 117

Toto Prihandi. (2008). Analisis Rasio Keungan, Jakarta : pengembangan

Uremadu, S. O. (2012). Working capital managment efficiency and corporate profitability: Evidences from quoted firms in Nigeria. Journal of Applied Finance \& Banking, 2(2), 215.

Wiagustini, N. L. P. (2014). Dasar-dasar Manajemen Keuangan (1st ed.). Denpasar: Udayana Press 
Utama, S. (2014). Aplikasi Analisis Kuantitatif (Edisi ke 8). Denpasar: Fakultas Ekonomi Universitas Udayana

Wiagustini, Ni Luh Putu. (2010). Dasar-dasar Manajemen Keuangan. Denpasar: Udayana University Press. 237.

Widayanti, L. P. P. A., \& Yadnya, I. P. (2020). Leverage, Profitabilitas, Dan Kepemilikan Manajerial Berpengaruh Terhadap Nilai Perusahaan Pada Perusahaan Real Estate Dan Property. E-Jurnal Manajemen Universitas Udayana, 9(2), 737. https:/ / doi.org/10.24843/ejmunud.2020.v09.i02.p17

Wirasedana, I. W. P. (2018). Pengaruh Keputusan Investasi, Keputusan Pendanaan, Kebijakan Dividen Dan Tingkat Inflasi Terhadap Nilai Perusahaan. E-Jurnal Akuntansi Universitas Udayana, 23(1) h: 813- 841. 